\title{
Synthesis and Certification of Lanthanum Oxide Extracted from Monazite Sand
}

\author{
Samin $^{1, *}$, Suyanti $^{1}$, Susanna Tuning Sunanti ${ }^{1}$, and Wisnu Ari Adi ${ }^{2}$ \\ ${ }^{1}$ Department of Process Technology, Center for Science and Accelerator Technology BATAN, \\ Jl. Babarsari, Kotak Pos 6101 ykbb, Yogyakarta 55281, Indonesia \\ ${ }^{2}$ Department of Science and Advanced Materials, Center for Science and Technology of Advanced Materials BATAN, \\ Kawasan PUSPITEK, Serpong, Tangerang Selatan, Banten, 15310, Indonesia
}

\section{* Corresponding author:}

tel: $+62-8156882743$

email:samin@batan.go.id

Received: March 19, 2019

Accepted: March 29, 2020

DOI: $10.22146 / \mathrm{ijc} .44327$

\begin{abstract}
Synthesis and certification of lanthanum oxide extracted from monazite sand have been carried out. This research aimed to increase the added value of monazite sand and obtain the lanthanum oxide in-house certified reference material (CRM). Synthesis of lanthanum oxide consists of several stages, namely: monazite sand digestion, rareearth elements hydroxide [REE $\left.(\mathrm{OH})_{3}\right]$ precipitation, Ce separation, $\mathrm{Nd}$ separation, lanthanum oxalate precipitation, and calcination. Certification of lanthanum oxide was carried out by determining the average concentration of the oxides and its uncertainty from the seven accredited laboratories by the ISO 35-2006 statistical method. Two other minerals in the lanthanum oxide analyzed by the XRD method were cerium hydroxide $\left[\mathrm{Ce}(\mathrm{OH})_{3}\right]$ and neodymium yttrium oxide fluoride $\left(\mathrm{Nd}_{2} \mathrm{Y}_{2} \mathrm{O}_{3} \mathrm{~F}_{16}\right)$. Lanthanum oxide certified contains ten oxides, with the two highest concentrations of $\mathrm{La}_{2} \mathrm{O}_{3}$ (91.662 \pm $0.007) \%$ and $\mathrm{Nd}_{2} \mathrm{O}_{3}(3.949 \pm 0.002) \%$. Lanthanum oxide has met the qualification inhouse CRM since it contained water less than 1\%, homogeneous, stable, and certified. $\mathrm{La}_{2} \mathrm{O}_{3}$ concentration in the lanthanum oxide in-house CRM from CSAT-BATAN, Indonesia was not significantly different in comparison to that from the Department of Chemical Engineering, Srinakharinwirot University, Thailand. Lanthanum oxide extracted from monazite sand can be used as reference material in determining the lanthanum oxide quality from the pilot plant process.
\end{abstract}

Keywords: synthesis; certification; lanthanum oxide; monazite sand

\section{- INTRODUCTION}

The synthesis and certification of lanthanum oxide extracted from the natural resources were not found, and the lanthanum oxide certified reference material also does not yet exist. Certified reference material (CRM) is a reference material characterized by a metrologically valid procedure for one or more specified properties. It is accompanied by a certificate, its associated uncertainty, and a statement of metrological traceability [1-3]. CRM is essential used for calibration, testing, and method validation [1-3].

The added value of monazite as a natural resource can be improved by processing monazite sand into lanthanum oxide in-house CRM [1,4]. Lanthanum oxide $\left(\mathrm{La}_{2} \mathrm{O}_{3}\right)$ is a potentially useful material for various optical and electronic applications, such as high gate dielectric material, capacitors, non-volatile memories, optical filters, and waveguides [5]. Lanthanum oxide has a bandgap of $4.3 \mathrm{eV}$ and the lowest lattice energy with a high dielectric constant [6]. Lanthanum oxide is a solid, odorless, white, and insoluble in water, but it is soluble in the dilute acids [7]. Nano-lanthanum oxide can be used for the preparation of organic chemical products catalysts and in automobile exhaust catalyst [8]. Trace analysis techniques applications based on the lanthanide spectroscopy have been found to detect many compounds up to parts per trillion (ppt) levels [9]. Lanthanum oxide is used widely in the film industry for studio lighting and projection [10]. The lanthanum oxide nanoscale can be used as a superconductor, exhaust gas converter, and hydrogen storage material [11]. 
Since lanthanum oxide has a high economic value, the research has emerged on how to get lanthanum oxide from minerals. Monazite is a mineral that has the form of phosphate bonds with Th and rare earth metals. In general, the chemical formula of monazite is (REE, Th) $\mathrm{PO}_{4}$ [12]. The processing of monazite sand to obtain lanthanum oxide was carried out through several stages. Monazite sand was fused with sulfuric acid, to obtain REE-sulfate, thorium-sulfate, and phosphoric acid. The REE-sulfate was melted with $\mathrm{NaOH}$, then REE-OH will be collected. REE-OH was dissolved with nitric acid and oxidized with oxidizing agents, so all rare earth metals will be oxidized and change oxidation state from II to III, except Ce, from oxidation state II to IV. The rare-earth was precipitated by using $\mathrm{NH}_{4} \mathrm{OH}$ at a specific $\mathrm{pH}$, so the rare earth metal was obtained individually. Lanthanum was precipitated as lanthanum oxalate, then calcined to obtain lanthanum oxide [13-14]. The steps for synthesis of the lanthanum oxide CRM are the preparation of lanthanum oxide, homogeneity study, stability study, characterization, and evaluation of uncertainty $[1,15]$. Certification of lanthanum oxide determines the average oxide concentration and the uncertainty by using the ISO 35-2006 statistical method $[2,16,18]$. It is expected that lanthanum oxide in-house CRM can be used as reference material to determine the quality of lanthanum oxide from the pilot plant process.

\section{- EXPERIMENTAL SECTION}

\section{Materials}

Indonesian monazite sand sample was obtained from Bangka Island. Chemicals including ammonia, sodium hydroxide, oxalic acid, hydrochloric acid, and nitric acid in the technical grade were purchased from Sodawaru Sidoarjo Indonesia without prior treatment and concentrated sulfuric acid, $\mathrm{KBrO}_{3}$, and lanthanum oxide standard were obtained from E-Merck, Germany.

\section{Instrumentation}

Instruments used included XRF Spectrometer Ortex 7010 (USA), XRD PANalytical X'Pert PRO PW3040/X0 (Netherlands), XRF Spectrometer Thermo Scientific ARL 9900 (Netherlands), and ball mill type Fritsch 05.4021522 (Germany).

\section{Procedure}

Synthesis of lanthanum oxide from monazite sand Precipitation of rare-earth elements hydroxide $\left[\operatorname{REE}(\mathrm{OH})_{3}\right.$ ] from monazite sand. Monazite sand was crushed until the particle size escapes 325 mesh. Monazite sand $50 \mathrm{~kg}$ was digested in the pilot plant using $\mathrm{NaOH} 96.43 \mathrm{~kg}$ at $140{ }^{\circ} \mathrm{C}$ for $4 \mathrm{~h}$ to dissolve the phosphate. Phosphate containing filtrate was stored for further processing, while the residue was washed using hot water then fed to a partial dissolution reactor. The residue was dissolved with $51.22 \mathrm{~L} \mathrm{HCl} 32 \%$ at $\mathrm{pH} 3.7$ and $80{ }^{\circ} \mathrm{C}$ for $2 \mathrm{~h}$. Ammonia 15\% (450.4 kg) was added into the filtrate to precipitate $\mathrm{U}$ and $\mathrm{Th}$. The filtrate was fed to the sedimentation reactor, and then $\mathrm{NH}_{4} \mathrm{OH}$ was added up to $\mathrm{pH}$ of 9.8 at room temperature for $1 \mathrm{~h}$, to form $\operatorname{REE}(\mathrm{OH})_{3}$ precipitate. The $\operatorname{REE}(\mathrm{OH})_{3}$ precipitate was filtered and dried in the oven at $110^{\circ} \mathrm{C}$ for $24 \mathrm{~h}$.

Synthesis of lanthanum oxide from $\operatorname{REE}(\mathrm{OH})_{3}$. $\mathrm{REE}(\mathrm{OH})_{3}(5 \mathrm{~kg})$ was dissolved with $18.02 \mathrm{~L}$ of $63 \%$ technical $\mathrm{HNO}_{3}$ solution, $0.25 \mathrm{~kg} \mathrm{KBrO}$, and heated at $135^{\circ} \mathrm{C}$ for $1 \mathrm{~h}$, then $40 \mathrm{~L}$ water was added to the solution, so the REE-nitrate solution was obtained. $\mathrm{NH}_{4} \mathrm{OH}$ solution was added into the REE-nitrate solution to obtain a $\mathrm{pH}$ of 4 , then $\mathrm{Ce}$ was precipitated as Cehydroxide. Further addition of $\mathrm{NH}_{4} \mathrm{OH}$ solution into the filtrate of the REE-nitrate solution until $\mathrm{pH} 8$, then $\mathrm{Nd}$ was precipitated as Nd-hydroxide.

A $3 \mathrm{~kg}$ of technical $\mathrm{H}_{2} \mathrm{C}_{2} \mathrm{O}_{4}$ was added into the filtrate of $\mathrm{La}\left(\mathrm{NO}_{3}\right)_{3}$ solution to obtain the La-oxalate precipitate. The $\mathrm{La}_{2}\left(\mathrm{C}_{2} \mathrm{O}_{4}\right)_{3}$ precipitate was filtered and dried in the oven at $110^{\circ} \mathrm{C}$ for $10 \mathrm{~h}$, Then the product was calcined at $1000{ }^{\circ} \mathrm{C}$ for $4 \mathrm{~h}$, to produce lanthanum oxide powder.

Preparation of lanthanum oxide in-house CRM. Lanthanum oxide $(350 \mathrm{~g})$ was dried at $110^{\circ} \mathrm{C}$ for $6 \mathrm{~h}$, crushed with a ball mill until the particle size escaped 200 mesh, and sieved for $2 \times 6 \mathrm{~h}$. Lanthanum oxide was homogenized for $6 \mathrm{~h}$ to obtain $300 \mathrm{~g}$ of the lanthanum oxide powder. Lanthanum oxide was tested for water content, homogeneity, stability, and then certification. The water content of lanthanum oxide was determined by the gravimetric method. The homogeneity test and the stability test of lanthanum oxide were carried out 
with the ISO 13528 statistical method. Certification of lanthanum oxide was carried out by the ISO 35-2006 statistical method $[16,18]$.

Lanthanum oxide powder was already qualified as the in-house CRM if the water content was less than $1 \%$, homogeneous, stable, and certification $[1,16,18]$.

\section{The water content test in lanthanum oxide}

The container was heated in an oven at $110^{\circ} \mathrm{C}$ for $1 \mathrm{~h}$, cooled in a desiccator for $1 \mathrm{~h}$, and weighed at room temperature. The weighing was carried out repeatedly until a constant weight was obtained. Lanthanum oxide sample $2.8 \mathrm{~g}$ was put into the container, heated in an oven at $110^{\circ} \mathrm{C}$ for $1 \mathrm{~h}$, cooled in a desiccator for $1 \mathrm{~h}$ and weighed at room temperature. The weighing was carried out repeatedly until a constant weight was obtained. Water content in lanthanum oxide was calculated from the wet weight minus the dry weight.

\section{The homogeneity test of lanthanum oxide}

Ten subsamples of lanthanum oxide were selected randomly. The weight of each subsample was $0.5 \mathrm{~g}$. Ten subsamples were analyzed for macroelement (La) and microelements (Sm, Y) in duplicate by the XRF method. All subsamples were analyzed by the same analyst with the same instrument on the same day and the same laboratory. Standard deviations between samples (Ss) of the ten subsamples duplo analysis data were processed with the ISO 13528 statistical method by the formula, as reported previously $[16,18]$.

Lanthanum oxide was homogeneous if Ss $\leq 0.3 \sigma$, where $\sigma$ was the standard deviation for proficiency assessment (SDPA), $\sigma$ can be established through CV Horwitz [16,18].

\section{Stability test of lanthanum oxide}

The stability tests can be carried out if lanthanum oxide has been stored for 3-6 months. The stability test was carried out in the same laboratory and the same analysis method as the homogeneity test. Lanthanum oxide was selected $g(g \geq 3)$ subsamples randomly. The weight of each subsample was $0.5 \mathrm{~g}$. Three subsamples were analyzed for macroelement $(\mathrm{La})$ and microelements $(\mathrm{Sm}, \mathrm{Y})$ in duplicate by the XRF method. The average concentration of each element in the stability test $\left(\mathrm{Y}_{\mathrm{T}}\right)$ was calculated from the first test $\left(\mathrm{Y}_{\mathrm{A}}\right)$ and the second test $\left(\mathrm{Y}_{\mathrm{B}}\right)$. The average stability test value $(\mathrm{Yr})$ was calculated from the $\mathrm{Y}_{\mathrm{T}}$ value of three subsamples. The absolute value of the difference between the average homogeneity test value $(\mathrm{Xr})$ and the average stability test value (Yr), $\mid \mathrm{Xr}$ - Yr| was calculated. Lanthanum oxide must be stable if $|\mathrm{Xr}-\mathrm{Yr}| \leq 0.3 \sigma[16,18]$.

\section{Characterization of lanthanum oxide}

The characterization of lanthanum oxide was carried out by the XRD method. Lanthanum oxide was characterized by the XRD PANalytical X'Pert PRO with the serial number of PW3040/X0. The scanning process of the lanthanum oxide sample was done at the angle of $2 \theta=0-4000^{\circ}$.

\section{Certification of lanthanum oxide}

The lanthanum oxide subsamples were distributed to the seven accredited laboratories, namely: Laboratory of Geological Survey Center Bandung, Laboratory of tekMIRA Center Bandung, Laboratory of PSTNT BATAN Bandung, Laboratory of PTBGN BATAN Jakarta, Laboratory of PSTBM BATAN Serpong, Laboratory of NAA PSTA BATAN Yogyakarta, and Laboratory of XRF PSTA BATAN Yogyakarta for testing the concentration and its uncertainty of the oxides.

The average oxide concentration and its uncertainty in lanthanum oxide from the seven laboratories were processed by the ISO 35-2006 statistical method as following $[16,18]$ :

The calculation of the average oxide concentration $(\overline{\mathrm{X}})$ was used the equation:

$$
\begin{aligned}
& \overline{\mathrm{X}}=\sum \mathrm{WiXi} \\
& \mathrm{Wi}=\frac{\mathrm{W}^{\prime}}{\sum_{\mathrm{i}=1}^{\mathrm{p}} \mathrm{Wi}^{\prime}} \\
& \mathrm{W}^{\prime}=\frac{1}{\mu^{2}}
\end{aligned}
$$

The calculation of the oxide concentration measurement uncertainty $(\mu)$ was performed with the equation:

$\mu(\overline{\mathrm{x}})=\sqrt{\sum \mathrm{W}_{\mathrm{i}}^{2}} \mu_{\mathrm{xi}}^{2}$

$\bar{X}$ : the average oxide concentration, $\mathrm{X}_{\mathrm{i}}$ : the oxide concentration of each laboratory, W: the weight of the 
Table 1. The composition of Indonesian monazite sand from Bangka [16], the number of replication $(\mathrm{n})=4-7$ laboratories

\begin{tabular}{cccccc}
\hline No & Oxide & Concentration (\%) & No & Oxide & Concentration (\%) \\
\hline 1 & $\mathrm{CeO}_{2}$ & $31.506 \pm 0.075$ & 11 & $\mathrm{Dy}_{2} \mathrm{O}_{3}$ & $1.029 \pm 0.011$ \\
2 & $\mathrm{La}_{2} \mathrm{O}_{3}$ & $13.165 \pm 0.038$ & 12 & $\mathrm{SiO}_{2}$ & $1.295 \pm 0.021$ \\
3 & $\mathrm{Nd}_{2} \mathrm{O}_{3}$ & $11.025 \pm 0.062$ & 13 & $\mathrm{U}_{3} \mathrm{O}_{8}$ & $0.298 \pm 0.005$ \\
4 & $\mathrm{ThO}_{2}$ & $6.283 \pm 0.022$ & 14 & $\mathrm{Fe}_{2} \mathrm{O}_{3}$ & $0.770 \pm 0.012$ \\
5 & $\mathrm{Y}_{2} \mathrm{O}_{3}$ & $3.931 \pm 0.024$ & 15 & $\mathrm{TiO}_{2}$ & $0.043 \pm 0.001$ \\
6 & $\mathrm{Pr}_{6} \mathrm{O}_{11}$ & $2.984 \pm 0.022$ & 16 & $\mathrm{Yb}_{2} \mathrm{O}_{3}$ & $0.310 \pm 0.004$ \\
7 & $\mathrm{P}_{2} \mathrm{O}_{5}$ & $19.109 \pm 0.102$ & 17 & $\mathrm{Er}_{2} \mathrm{O}_{3}$ & $0.412 \pm 0.005$ \\
8 & $\mathrm{SnO}_{2}$ & $1.034 \pm 0.004$ & 18 & $\mathrm{Al}_{2} \mathrm{O}_{3}$ & $0.826 \pm 0.021$ \\
9 & $\mathrm{Sm}_{2} \mathrm{O}_{3}$ & $1.956 \pm 0.005$ & 19 & $\mathrm{CaO}$ & $0.219 \pm 0.006$ \\
10 & $\mathrm{Gd}_{2} \mathrm{O}_{3}$ & $1.981 \pm 0.003$ & 20 & $\mathrm{ZrO}_{2}$ & $0.177 \pm 0.005$ \\
\hline
\end{tabular}

oxide and $\mu$ : the oxide concentration measurement uncertainty.

\section{- RESULTS AND DISCUSSION}

It was necessary to know the composition of monazite sand as raw material for the synthesis of lanthanum oxide in the pilot plant. The composition of Indonesian monazite sand from Bangka was presented in Table 1. It was observed that the major components of monazite sand were $\mathrm{CeO}_{2}, \mathrm{La}_{2} \mathrm{O}_{3}, \mathrm{Nd}_{2} \mathrm{O}_{3}$, and $\mathrm{P}_{2} \mathrm{O}_{5}$. Monazite sand contains $\mathrm{CeO}_{2}: 31.506 \%, \mathrm{La}_{2} \mathrm{O}_{3}: 13.165 \%$, $\mathrm{Nd}_{2} \mathrm{O}_{3}: 11.025 \%$ and $\mathrm{P}_{2} \mathrm{O}_{5}: 19.109 \%$. So monazite sand can be processed into $\operatorname{REE}(\mathrm{OH})_{3}$ and then lanthanum oxide.

\section{Synthesis of Lanthanum Oxide from Monazite Sand}

\section{Precipitation of $\operatorname{REE}(\mathrm{OH}) 3$ from monazite sand}

The composition of $\operatorname{REE}(\mathrm{OH})_{3}$ resulting from monazite sand was presented in Table 2. From the data in

Table 2. The composition of $\operatorname{REE}(\mathrm{OH})_{3}$ processed from monazite sand, the number of replication $(\mathrm{n})=3$

\begin{tabular}{ccc}
\hline No & Element & Concentration (\%) \\
\hline 1 & $\mathrm{Ce}$ & $28.711 \pm 0.073$ \\
2 & $\mathrm{La}$ & $16.274 \pm 0.013$ \\
3 & $\mathrm{Nd}$ & $4.633 \pm 0.016$ \\
4 & $\mathrm{Pr}$ & $1.847 \pm 0.009$ \\
5 & $\mathrm{Y}$ & $1.449 \pm 0.008$ \\
6 & $\mathrm{Gd}$ & $1.391 \pm 0.009$ \\
7 & $\mathrm{Sm}$ & $0.664 \pm 0.038$ \\
8 & $\mathrm{Dy}$ & $0.293 \pm 0.006$ \\
9 & $\mathrm{Er}$ & $0.171 \pm 0.001$ \\
\hline
\end{tabular}

Table 2, $\mathrm{REE}(\mathrm{OH})_{3}$ contains major components of Ce: $28.711 \%$, La: $16.274 \%$, and Nd: $4.633 \%$, while $\mathrm{P}$ and $\mathrm{Th}$ were not detected. The Ce element was the most dominant, so firstly $\mathrm{Ce}$ must be separated from $\mathrm{REE}(\mathrm{OH})_{3}$, then followed by separation of $\mathrm{Nd}$ so that a higher La concentration was obtained.

\section{Separation of Ce from REE $(\mathrm{OH})_{3}$}

For the separation of Ce, $\operatorname{REE}(\mathrm{OH})_{3}$ was dissolved with nitric acid, in the $\operatorname{REE}\left(\mathrm{NO}_{3}\right)_{3}$ solution was added with $\mathrm{NH}_{4} \mathrm{OH}$ solution to obtain a $\mathrm{pH}$ of 4 . Ce was precipitated as Ce-hydroxide.

The reaction of rare earth elements hydroxide with nitric acid is shown below [13,19,21]:

$(\mathrm{REE})(\mathrm{OH})_{3}+3 \mathrm{HNO}_{3} \rightarrow(\mathrm{REE})\left(\mathrm{NO}_{3}\right)_{3}+3 \mathrm{H}_{2} \mathrm{O}$

\section{Separation of $\mathrm{Nd}$ from the REE-nitrate solution}

The next step was the separation of $\mathrm{Nd}$. The filtrate of the REE-nitrate solution was added with $\mathrm{NH}_{4} \mathrm{OH}$ solution to obtain a $\mathrm{pH}$ of 8 , then $\mathrm{Nd}$ was precipitated as neodymium hydroxide. The precipitation reaction of neodymium hydroxide [13,21]:

$\mathrm{Nd}\left(\mathrm{NO}_{3}\right)_{3}+3 \mathrm{NH}_{4} \mathrm{OH} \rightarrow \mathrm{Nd}(\mathrm{OH})_{3} \downarrow+3 \mathrm{NH}_{4} \mathrm{NO}_{3}$

\section{Precipitation of lanthanum oxalate from the lanthanum nitrate solution}

After Ce and $\mathrm{Nd}$ were separated, oxalic acid was added to the lanthanum nitrate solution, and the white precipitate formed was lanthanum oxalate.

\section{Synthesis of lanthanum oxide}

Lanthanum oxalate processed from monazite sand 
was calcined at $1000{ }^{\circ} \mathrm{C}$ for $4 \mathrm{~h}$, then lanthanum oxide powder was obtained.

\section{The Water Content Test in Lanthanum Oxide}

Based on the data in Table 3, the water content in lanthanum oxide was $0.181 \%$ to obtain water content less than $1 \%$. The powder of lanthanum oxide has been qualified for certification. So the homogeneity test and the stability test could be done.

\section{Homogeneity Test of Lanthanum Oxide}

The homogeneity test of lanthanum oxide can be seen in Supplement 1 (S-1), Supplement 2 (S-2), and Supplement 3 (S-3). Lanthanum oxide was homogeneous if Ss $\leq 0.3 \sigma$, both for the macroelement (La) and the microelements $(\mathrm{Sm}, \mathrm{Y})$. The concentration of $\mathrm{La}, \mathrm{Sm}$, and $\mathrm{Y}$ has been homogeneous as shown in supplement 1, 2, and 3, respectively.. Based on the homogeneity test of the macroelement (La), and the microelements (Sm, Y), lanthanum oxide has been homogenous.

\section{Stability Test of Lanthanum Oxide}

The stability test of lanthanum oxide can be seen in Supplement 4 (S-4), Supplement 5 (S-5), and Supplement 6 (S-6). Lanthanum oxide is stable if $\mid \mathrm{Xr}$ $\mathrm{Yr} \mid \leq 0.3 \sigma$, both for macroelement (La) and microelements (Sm, Y). In Supplement 4, the concentration of $\mathrm{La}, \mathrm{Sm}$, and $\mathrm{Y}$ was found to be stable as given in supplement 4,5 , and 6 , respectively. Based on the stability test of macroelement (La) and microelements $(\mathrm{Sm}, \mathrm{Y})$, lanthanum oxide has been stable.

\section{Characterization of Lanthanum Oxide}

The characterization results of lanthanum oxide made in CSAT BATAN and lanthanum oxide made in EMerck Germany by using the XRD method were presented in Fig. 1. Lanthanum oxide produced in CSAT BATAN (a) contains the minerals of cerium hydroxide $\left[\mathrm{Ce}(\mathrm{OH})_{3}\right]$, lanthanum oxide $\left(\mathrm{La}_{2} \mathrm{O}_{3}\right)$, neodymium yttrium oxide fluoride $\left(\mathrm{Nd}_{2} \mathrm{Y}_{2} \mathrm{O}_{3} \mathrm{~F}_{16}\right)$, yttrium oxide $\left(\mathrm{Y}_{2} \mathrm{O}_{3}\right)$, and potassium barium niobium uranium oxide

Table 3. Water content test in lanthanum oxide by gravimetric method

\begin{tabular}{ccccc}
\hline $\begin{array}{c}\mathrm{La}_{2} \mathrm{O}_{3} \\
\text { sub-sample }\end{array}$ & $\begin{array}{c}\text { Wet weight } \\
(\mathrm{g})\end{array}$ & $\begin{array}{c}\text { Dry weight } \\
(\mathrm{g})\end{array}$ & $\begin{array}{c}\text { Water content } \\
(\%)\end{array}$ & $\begin{array}{c}\text { Average water } \\
\text { content }(\%)\end{array}$ \\
\hline 1 & 2.879 & 2.882 & 0.104 & \\
2 & 2.799 & 2.803 & 0.143 & \\
3 & 2.838 & 2.844 & 0.211 & \\
4 & 2.891 & 2.897 & 0.208 & $0.181 \pm 0.046$ \\
5 & 2.856 & 2.862 & 0.210 & \\
6 & 2.886 & 2.892 & 0.208 & \\
\hline
\end{tabular}

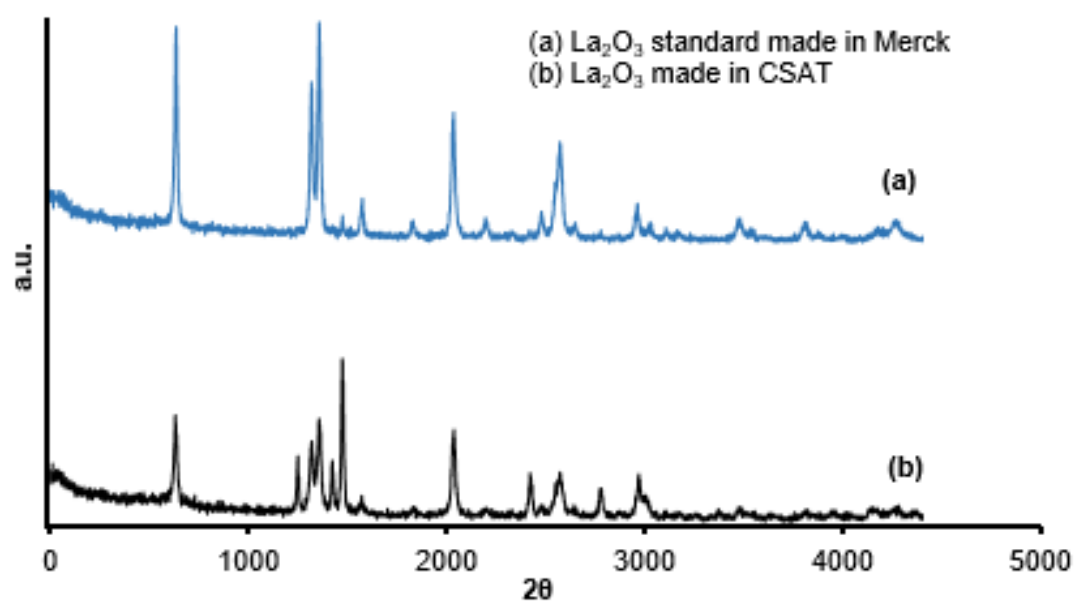

Fig 1. The XRD patterns of (a) lanthanum oxide made in CSAT BATAN and (b) lanthanum oxide made in E-Merck Germany 
Table 4. The determination of the average $\mathrm{La}_{2} \mathrm{O}_{3}$ concentration and its uncertainty in the lanthanum oxide from the seven laboratories, the number of replication $(\mathrm{n})=3$

\begin{tabular}{|c|c|c|c|c|c|c|}
\hline Laboratory & $\mathrm{Xi}(\%)$ & $\mu \mathrm{i}(\%)$ & $\mathrm{Wi}^{\prime}$ & $\mathrm{Wi}$ & Wi Xi & $\mathrm{Wi}^{2} \mu \mathrm{i}^{2}$ \\
\hline A & 92.573 & 0.227 & 19.4065 & 0.1350 & 12.5005 & $9.4 \times 10^{-4}$ \\
\hline B & 91.705 & 0.118 & 71.8184 & 0.4997 & 45.8271 & $3.5 \times 10^{-3}$ \\
\hline C & 91.957 & 2.394 & 0.1745 & 0.0012 & 0.1117 & $8.5 \times 10^{-6}$ \\
\hline $\mathrm{D}$ & 94.167 & 0.903 & 1.2265 & 0.0085 & 0.8037 & $5.9 \times 10^{-5}$ \\
\hline E & 91.190 & 0.140 & 51.0204 & 0.3550 & 32.3731 & $2.5 \times 10^{-3}$ \\
\hline $\mathrm{F}$ & 95.112 & 8.327 & 0.0144 & 0.0001 & 0.0096 & $7.0 \times 10^{-7}$ \\
\hline G & 93.352 & 4.233 & 0.0558 & 0.0004 & 0.0363 & $3.0 \times 10^{-6}$ \\
\hline Total & & & 143.7165 & & & \\
\hline $\mathrm{X}_{\text {average }}$ & & & & & 91.6620 & \\
\hline$\mu_{\mathrm{x}}$ & & & & & & $7.0 \times 10^{-3}$ \\
\hline
\end{tabular}

$\left(\mathrm{Nb}_{7.6} \mathrm{U}_{2.4} \mathrm{Ba}_{5.2} \mathrm{~K}_{8} \mathrm{O}_{30}\right)$. Lanthanum oxide made in E-Merck Germany (b) contains the minerals of lanthanum deuteriohydroxide $\left[\mathrm{La}(\mathrm{OD})_{3}\right]$, cerium (Ce), scandium strontium fluoride $\left(\mathrm{ScSr}_{1.56} \mathrm{~F}_{6.1}\right)$ and zirconium iron antimonide $\left(\mathrm{ZrFe}_{0.68} \mathrm{Sb}\right)$.

\section{Certification of Lanthanum Oxide}

The certification of lanthanum oxide such as the determination of the average oxide concentration and its uncertainty from the seven laboratories accredited was processed by the ISO 35-2006 statistical method $[1,16,18]$. The average oxide concentration $\left(\mathrm{X}_{\text {average }}\right)$ was determined using Eq. 1, 2, and 3, while the determination of the uncertainty $(\mu)$ was using Eq. 4 . The determination of the average $\mathrm{La}_{2} \mathrm{O}_{3}$ concentration and uncertainty from the seven laboratories that were processed by the ISO 35-2006 statistical method were presented in Table 4.

From the data in Table $4, \mathrm{La}_{2} \mathrm{O}_{3}$ concentrations in the lanthanum oxide from the seven laboratories were varied from $91.190 \%$ to $95.112 \%$. With the ISO $35-2006$ statistical method, the average $\mathrm{La}_{2} \mathrm{O}_{3}$ concentration was obtained $91.662 \%$ with an uncertainty of $0.007 \%$.

The average concentration and other oxide uncertainties from the seven laboratories were determined in the same method. Certificate of the average oxide concentration and its uncertainty in the lanthanum oxide was presented in Table 5 .

Based on the data in Table 5, certificate of the lanthanum oxide consists of ten oxides i.e., $\mathrm{La}_{2} \mathrm{O}_{3}, \mathrm{Nd}_{2} \mathrm{O}_{3}$,
$\mathrm{CeO}_{2}, \mathrm{Pr}_{6} \mathrm{O}_{11}, \mathrm{Y}_{2} \mathrm{O}_{3}, \mathrm{Sm}_{2} \mathrm{O}_{3}, \mathrm{~Tb}_{4} \mathrm{O}_{7}, \mathrm{CaO}, \mathrm{SiO}_{2}$, and $\mathrm{Al}_{2} \mathrm{O}_{3}$. The concentration of $\mathrm{La}_{2} \mathrm{O}_{3}$ was obtained (91.662 \pm $0.007) \%$, while $\mathrm{ThO}_{2}$ and $\mathrm{U}_{3} \mathrm{O}_{8}$ were not detected.

The evaluation of data was obtained that lanthanum oxide has been homogeneous, stable, water content less than $1 \%$, and certificated. So the lanthanum oxide powder was already qualified as the in-house CRM. From the data in Table 6, the major oxides in lanthanum oxide in-house CRM products from CSATBATAN, Indonesia were $\mathrm{La}_{2} \mathrm{O}_{3}: 91.662 \%, \mathrm{Nd}_{2} \mathrm{O}_{3}$ : $3.949 \%, \mathrm{CeO}_{2}: 2.426 \%$, and $\mathrm{Pr}_{6} \mathrm{O}_{11}: 1.217 \%$. The major oxide in the lanthanum oxide product from the Department of Chemical Engineering, Srinakharinwirot University (DCE, SU), Thailand was $\mathrm{La}_{2} \mathrm{O}_{3}$ : 95.360\% only,

Table 5. Certificate of the average oxide concentration and its uncertainty in the lanthanum oxide

\begin{tabular}{llcc}
\hline No & Oxide & $\begin{array}{c}\text { Average } \\
\text { Concentration (\%) }\end{array}$ & Uncertainty (\%) \\
\hline 1 & $\mathrm{La}_{2} \mathrm{O}_{3}$ & 91.662 & 0.007 \\
2 & $\mathrm{Nd}_{2} \mathrm{O}_{3}$ & 3.949 & 0.002 \\
3 & $\mathrm{CeO}_{2}$ & 2.426 & 0.040 \\
4 & $\mathrm{Pr}_{6} \mathrm{O}_{11}$ & 1.217 & 0.003 \\
5 & $\mathrm{Y}_{2} \mathrm{O}_{3}$ & 0.114 & 0.002 \\
6 & $\mathrm{Sm}_{2} \mathrm{O}_{3}$ & 0.144 & 0.007 \\
7 & $\mathrm{~Tb}_{4} \mathrm{O}_{7}$ & 0.106 & 0.005 \\
8 & $\mathrm{CaO}_{9}$ & 0.199 & 0.004 \\
9 & $\mathrm{SiO}_{2}$ & 0.074 & 0.003 \\
10 & $\mathrm{Al}_{2} \mathrm{O}_{3}$ & 0.061 & 0.002 \\
\hline \multicolumn{5}{c}{$\mathrm{Total}^{2}$} \\
\hline
\end{tabular}


Table 6. The comparison of the lanthanum oxide in-house CRM (La-oxide CRM) from CSAT-BATAN Indonesia, the lanthanum oxide (La-oxide) from DCE-SU Thailand, and REE-oxide from DRI-ME Myanmar by precipitation methods

\begin{tabular}{|c|c|c|c|c|}
\hline \multirow{3}{*}{ No } & \multirow{3}{*}{ Composition } & \multicolumn{3}{|c|}{ Concentration (\%) } \\
\hline & & La-oxide CRM from & La-oxide from & REE-oxide from \\
\hline & & CSAT-BATAN, Indonesia & DCE-SU, Thailand [22] & DRI-ME, Myanmar [17] \\
\hline 1 & $\mathrm{La}_{2} \mathrm{O}_{3}$ & $91.662 \pm 0.007$ & 95.360 & 25.173 \\
\hline 2 & $\mathrm{Nd}_{2} \mathrm{O}_{3}$ & $3.949 \pm 0.002$ & 0.250 & 14.215 \\
\hline 3 & $\mathrm{CeO}_{2}$ & $2.426 \pm 0.040$ & 0.940 & 51.530 \\
\hline 4 & $\mathrm{Pr}_{6} \mathrm{O}_{11}$ & $1.217 \pm 0.003$ & n.d & 3.204 \\
\hline 5 & $\mathrm{Y}_{2} \mathrm{O}_{3}$ & $0.114 \pm 0.002$ & n.d & 0.547 \\
\hline 6 & $\mathrm{Sm}_{2} \mathrm{O}_{3}$ & $0.144 \pm 0.007$ & n.d & 0.737 \\
\hline 7 & $\mathrm{~Tb}_{4} \mathrm{O}_{7}$ & $0.106 \pm 0.005$ & n.d & n.d \\
\hline 8 & $\mathrm{Gd}_{2} \mathrm{O}_{3}$ & n.d & n.d & 0.381 \\
\hline 9 & $\mathrm{ThO}_{2}$ & n.d & n.d & n.d \\
\hline 10 & $\mathrm{U}_{3} \mathrm{O}_{8}$ & n.d & n.d & n.d \\
\hline 11 & $\mathrm{CaO}$ & $0.199 \pm 0.004$ & 2.290 & n.d \\
\hline 12 & $\mathrm{SiO}_{2}$ & $0.074 \pm 0.003$ & $<0.010$ & n.d \\
\hline 13 & $\mathrm{Al}_{2} \mathrm{O}_{3}$ & $0.061 \pm 0.002$ & 0.334 & n.d \\
\hline
\end{tabular}

and the major oxides in REE-oxide products from the Department of Research and Innovation, Ministry of Education (DRI-ME), Myanmar were $\mathrm{La}_{2} \mathrm{O}_{3}: 25.173 \%$, $\mathrm{Nd}_{2} \mathrm{O}_{3}: 14.125 \%, \mathrm{CeO}_{2}: 51.530 \%$, and $\operatorname{Pr}_{6} \mathrm{O}_{11}: 3.204 \%$.

Based on the lanthanum oxide composition test data from the seven laboratories, it was found that the uncertainty of each component varied from 0.002$0.040 \%$, so the lanthanum oxide can be used as reference material in determining the lanthanum oxide quality from the pilot plant process.

\section{- CONCLUSION}

Lanthanum oxide certified contained ten oxides, and four oxides with the highest concentration included $\mathrm{La}_{2} \mathrm{O}_{3}(91.662 \pm 0.007) \%, \mathrm{Nd}_{2} \mathrm{O}_{3}(3.949 \pm 0.002) \%, \mathrm{CeO}_{2}$ $(2.426 \pm 0.040) \%, \operatorname{Pr}_{6} \mathrm{O}_{11}(1.217 \pm 0.003) \%$. Two other minerals in the lanthanum oxide by the XRD method were cerium hydroxide $\left[\mathrm{Ce}(\mathrm{OH})_{3}\right]$ and neodymium yttrium oxide fluoride $\left(\mathrm{Nd}_{2} \mathrm{Y}_{2} \mathrm{O}_{3} \mathrm{~F}_{16}\right)$. Lanthanum oxide was already qualified as the in-house CRM since it contained water less than $1 \%$, homogeneous, stable, and certified. $\mathrm{La}_{2} \mathrm{O}_{3}$ concentration in the lanthanum oxide inhouse CRM from CSAT-BATAN, Indonesia was not significantly different compared to that from the Department of Chemical Engineering, Srinakharinwirot University, Thailand (the difference level was 3.70\%). The lanthanum oxide extracted from monazite sand can be used as reference material in determining the lanthanum oxide quality from the pilot plant process.

\section{- ACKNOWLEDGMENTS}

The author thanks Dr. Susilo Widodo who has agreed to the 2017 Budget (DIPA) of the Center for Science and Accelerator Technology-BATAN to financing this research. The authors are also grateful to Sutanto WW, Bambang Irianto, Dwi Purnomo, Suhardi, and Mulyono, who have helped with this research.

\section{- REFERENCES}

[1] Guimarães, E.F., do Rego, E.C.P., Cunha, H.C.M., Rodrigues, J.M., and Figueroa-Villar, J.D., 2014, Certified reference material for traceability in environmental analysis: PAHs in toluene, J. Braz. Chem. Soc., 25 (2), 351-360.

[2] Quan, C., Yao, H., and Hou, C., 2013, Certification and uncertainty evaluation of flavonoids certified reference materials, Agric. Sci., 4 (9B), 89-96.

[3] Samin, and Sunanti, S.T., 2018, Analysis methods for development of certified reference materials (CRM) zircon minerals synthesis, Indones. J. Chem., 18 (3), 448-456.

[4] Satusinprasert, P., Suwanmance, U., and Rattanaphra, D., 2015, Separation of light and middle-heavy rare earth from nitrate medium by 
liquid-liquid extraction, Kasetsart J. (Nat. Sci.), 49 (1), 155-163.

[5] Karthikeyan, S., and Selvapandiyan, M., 2017, Synthesis of nanocrystalline lanthanum oxide $\mathrm{La}_{2} \mathrm{O}_{3}$ powder at reflux routes, Int. J. Comput. Sci. Commun. Netw., 7 (3), 70-78.

[6] Lim, S.R., Lee, S.D., Kim, H.S., Simanjuntak, F.S.H., and Lee, H., 2014, Lanthanum oxide-catalyzed transesterification of dimethyl carbonate with glycerol: Effect of surfactant, Bull. Korean Chem. Soc., 35 (11), 3163-3168.

[7] Ammary, E., and Kangarlou, H., 2016, Investigation of the optical properties of lanthanum oxide, using density functional theory and LSDA and WC approximations, Int. J. Pharm. Res. Allied Sci., 5 (2), 436-441.

[8] Saravani, H., and Khajehali, M., 2016, Synthesis and characterization of lanthanum oxide and lanthanum oxide carbonate nanoparticles from thermalizes of $\mathrm{La}$ (acacen) $\left(\mathrm{NO}_{3}\right)\left(\mathrm{H}_{2} \mathrm{O}\right)$ complex, Orient. J. Chem., 31 (4), 2351-2357.

[9] Shah, M.S., and Jan, G.M., 2016, Lanthanum oxide nanoparticles synthesis and their luminescent property, Indo Am. J. Pharm. Sci., 3 (1), 81-85.

[10] Hastiawan, I., Firmansyah, F., Juliandri, Rakhmawaty, D., and Noviyanti, A.R., 2016, Pemisahan lanthanum dari limbah hasil pengolahan timah dengan menggunakan metode pengendapan bertingkat, Chimica et Natura Acta, 4 (2), 93-96.

[11] Xue, S., Wu, W., Bian, X., Wang, Z., and Yang, Z., 2014, Synthesis of lanthanum oxide using lanthanum chloride by hydrogen-oxygen flame pyrolysis route, Appl. Mech. Mater., 633-634, 499-503.

[12] Bahri, C.N.A.C.Z., Al-Areqi, W.M., Ab Majid, A., and Mohd Ruf, M.I.F., 2016, Production of rare earth elements from Malaysian monazite by selective precipitation, Malays. J. Anal. Sci., 20 (1), 44-50.

[13] Purwani, M.V., and Suyanti, 2005, Pengaruh $\mathrm{HNO}_{3}$ dan $\mathrm{KBrO}_{3}$ pada pembuatan konsentrat Ce, La dan
Nd dari pasir monasit, Prosiding PPI-PDIPTN 2005, 194-202.

[14] Rodliyah, I., Rochani, S., and Wahyudi, T., 2015, Extraction of rare earth metals from monazite mineral using the acid method, Indones. Min. J., 18 (1), 39-45.

[15] Gong, N., Guo, Y., Yang, N., Gao, Z., Du, G., and Lu, Y., 2012, Preparation and characterization of new certified reference material of puerarin (GBW09511), Anal. Methods, 4 (10), 3443-3447.

[16] Samin, Sunanti, S.T., and Setiawan, K., 2018, The synthesis and certification of in-house monazite sand certified reference materials, AIP Conf. Proc., 2014, 020148.

[17] Tar, A.T., Myo, T.Z., Hlaing, T.M., and Win, B.B.M., 2017, Study on the processing of rare earth oxide from monazite, Mongmit Myitsone region, ASRJETS, 27 (1), 43-51.

[18] Samin, Suyanti, and Sunanti, S.T., 2018, The synthesis and certification of cerium oxide certified reference materials (CRM) as a processed result of monazite sand, AIP Conf. Proc., 2014, 020049.

[19] Purwani, M.V., Trinopiawan, K., Poernomo, H., Suyanti, Pusporini, N.D., and Amiliana, R.A., 2019, Separation of $\mathrm{Ce}$, La and $\mathrm{Nd}$ rare-earth hydroxide (REOH) by oxidation with potassium permanganate and precipitation, J. Phys. Conf. Ser., 1198 (3), 032003.

[20] Purwani, M.V., Triyono, Suprihati, Sudibyo, R., and Suyanti, 2018, Pemisahan lantanum, cerium dan neodimium melalui dekomposisi termal dan leaching memakai $\mathrm{HNO}_{3}$ encer, Prosiding PPIPDIPTN 2018, 171-1778.

[21] Pusporini, N.D., Suyanti, Amiliana, R.A., and Poernomo, H., 2020, Processing, and refining of tin tailing mining, J. Phys. Conf. Ser., 1436, 012136.

[22] Lerdtrakulwong, O., Prucksawan, E., Suwanmanee, U., and Rattanaphra, D., 2013, Synthesis of lanthanum oxide powder by precipitation method, Burapha University International Conference, Pattaya, Thailand, 4-6 July 2013. 